\title{
Microsatellite DNA Polymorphism of Channa marulius Inhabiting River Jhelum
}

\author{
Uzma Hussain $^{1,{ }^{*}}{ }^{(}$, Khalid Abbas ${ }^{1}$, Tanveer Ahmed ${ }^{1,2}$, Iram Qadeer ${ }^{1,3}$ \\ ${ }^{1}$ University of Agriculture, Department of Zoology, Wildlife and Fisheries, Faisalabad, Punjab, Pakistan. \\ ${ }^{2}$ Khwaja Fareed University of Engineering and Information Technology, Rahim Yar Khan, Pakistan. \\ ${ }^{3}$ Government Sadiq College Women University, Bahawalpur, Punjab, Pakistan.
}

\section{Article History}

Received August 5, 2019

Accepted November 18, 2019

First Online November 27, 2019

\section{Corresponding Author}

Tel.: 923346267873

E-mail: uzmahussain13@gmail.com

\section{Keywords}

Wild fish

Genetic Structure

Genetic differentiation

Inbreeding

SSR Markers

\begin{abstract}
Wild populations of $C$. marulius have undergone a steady decline due to habitat deterioration, overexploitation and aquatic pollution. Genetic polymorphism by using microsatellite DNA markers was analyzed in natural populations of $C$. marulius. Samples were collected from different sites of river Jhelum viz. Trimu Headworks, Rasul Barrage, Mangla Dam, Jhelum Bridge, and Marala Dhand. A total of five microsatellite loci (CA05, CAO7, CAO8, CAO9, and CA10) were used to evaluate genetic polymorphism. The overall populations of $C$. marulius showed a moderate level of heterozygosity. The mean observed heterozygosity $(\mathrm{Ho})$ at all the five loci was 0.43 whereas expected heterozygosity $(\mathrm{He})$ was 0.54 . The pairwise population genetic differentiation (FST) ranged in between 0.000001 to 0.231955 . Analysis of molecular variance (AMOVA) revealed that majority of variations among populations than within populations $62.05 \%$ and $33.03 \%$, respectively. Significant deviation $(P<0.05)$ from Hardy-Weinberg equilibrium was seen in all the populations with clear deficit heterozygosity suggesting inbreeding. A UPGMA tree based on Nei's genetic distance matrix revealed that $C$. marulius populations were divided into two major clusters. Principle component analysis showed same clustering pattern. The present study about genetic structure of $C$. marulius populations will be fruitful for effective management and conservation of fisheries resources.
\end{abstract}

\section{Introduction}

The Channidae family consists two genera; Channa and Parachanna. The genus Channa is widely distributed in Asian countries like Iran, China, Korea, India, Pakistan, Sri Lanka, Vietnam, Thailand, Malaysia and Indonesia (Musikasinthorn, 2001).

The fresh water ecosystem of Pakistan is representative and diversified with many of warm water fish species. C. marulius also known as snakehead locally, is one of the most important riverine freshwater food fish and widely distributed in Asia (Berra, 2007). C. marulius has attained the significant importance because of their freely distribution, abundance in nature and high market worth. The distribution of this predatory fish is extending into Azad Jamu Kashmir, Punjab, Sindh, Khyber Pakhtunkhwa and Balochistan Provinces of Pakistan. The dispersal status of $C$. marulius is indigenous and acquired near threatened status according to the survey of IUCN (Rafique \& Khan, 2012).

During the last few decades, wild populations of $C$. marulius has undergone a steady decline due to habitat loss, over exploitation, exotic species invasion, disease, pollution and poisoning (Molur \& Walker, 1998).

Studying population genetic structure of wild fish species provides valuable information for rising conservation and management strategies for fishes having endangered status. Gaining information about the genetic structure of cultivable fish species is also essential for selective breeding programs, identification 
of potential broodstock, stock enhancement, and management for sustainable yield and conservation of biodiversity (Haniffa, Nagarajan, Gopalakrishnan, \& Musammilu, 2007).

The potential of molecular markers to fisheries management has long been recognized (Utter, 1991). The characterization of molecular markers and studying genetic diversity of $C$. marulius is important because such information is valuable in fishery management, breeding programs and genetic stock identification (Chondar, 1999).

Microsatellites are molecular markers that are most common and versatile due to their small size, high level of polymorphism and rapid detection protocols (Estoup \& Angers, 1998). These markers are extensively used in population genetics and evolution for addressing questions in the related field (Chistiakov, Hellemans, \& Volckaert, 2006). Microsatellite loci are abundantly distributed throughout the eukaryotic genome and each locus is characterized by a conserved DNA sequence. These sequences consist of both unique DNA and a repetitive DNA motif (Scribner \& Pearce, 2000). The usefulness of microsatellites as genetic markers is based on their inherent variability. Thus, due to their extreme polymorphism, microsatellite loci are considered ideal markers for forensic identification, parentage testing, gene mapping, conservation biology and population genetics (Jarne \& Lagoda, 1996; Peakall, Gilmore, Keys, Morgante, \& Rafalski, 1998).

Among the tributary of River Indus, River Jhelum is one of them which irrigate the plain areas of Punjab province in Pakistan. The important engineering structure on the River Jhelum is Mangla Dam, Rasul Barrage and at the confluence of River Chenab, the Trimu Headworks. Ichthyofaunal information of River Jhelum is very poor (Mirza \& Javed, 2006).

The present study objective was to analyze the genetic polymorphism among $C$. marulius populations endemic River Jhelum, Pakistan using microsatellite DNA markers. The inferences of this study will provide genetic data base for the policy making regarding conservation and management of fish species.

\section{Materials and Methods}

\section{Sampling and DNA Isolation}

In the present study a total of 125 C. marulius specimens were collected from five sampling localities including Marala Dhand (MR) (32 $39^{\prime} 14.16^{\prime \prime} \mathrm{N}, 73^{\circ} 26^{\prime}$ 56.24" E), Mangla Dam (MD) $\left(33.142083^{\circ} \mathrm{N}\right.$, $\left.73.645015^{\circ} \mathrm{E}\right)$, Jhelum Bridge (JB) (32 ${ }^{\circ} 55^{\prime} 30.51^{\prime \prime} \mathrm{N}, 73^{\circ}$ $\left.44^{\prime} 37.39^{\prime \prime} \mathrm{E}\right)$, Rasul Barrage (RB) (32 $40^{\circ} 42.66^{\prime \prime} \mathrm{N}, 73^{\circ}$ $30^{\prime} 334.84^{\prime \prime} \mathrm{E}$ ) and Trimu Headworks (TH) (31 03' 45.96 $\left.\mathrm{N}, 70^{\circ} 12^{\prime} 33.30^{\circ} \mathrm{E}\right)$ on River Jhelum of Punjab, Pakistan (Figure 1). The samples were tagged according to site code and immediately freeze them by placing in crushed ice boxes at temperature $-20^{\circ} \mathrm{C}$ for transporting them to the Aquaculture Biotechnology Laboratory, University of Agriculture, Faisalabad.

Total genomic DNA was extracted by using Chloroform-Isoamyl-Alcohol protocol with minor changes followed by Yue and Orban (2005). The quality and concentration of DNA were assessed on $0.8 \%$ Agarose Gel. The required quantity of DNA dilutions was made for PCR amplifications.

\section{Amplification of Microsatellite Loci}

For microsatellite analysis, five polymorphic loci (Table 1) were amplified through the PCR. The PCR was carried out in $20 \mu \mathrm{l}$ that contain DNA templates, Taq polymerase $(0.4 \mu \mathrm{l})$, dNTPs $(0.4 \mu \mathrm{l}), 0.4 \mu \mathrm{l}$ of each primer and reaction buffer that include tris $\mathrm{HCl}$, gelatin $0.01 \%$, $\mathrm{MgCl}_{2}$ and $\mathrm{KCl}(2.0 \mu \mathrm{l})$ in a thermocycler. Denaturation was carried out at $95^{\circ} \mathrm{C}$ for $5 \mathrm{~min} 30 \mathrm{cycles}$ of $60 \mathrm{~s}$ at $94^{\circ} \mathrm{C}$, $60 \mathrm{~s}$ for annealing temperature and elongation for $9 \mathrm{~min}$ at $72^{\circ} \mathrm{C}$.

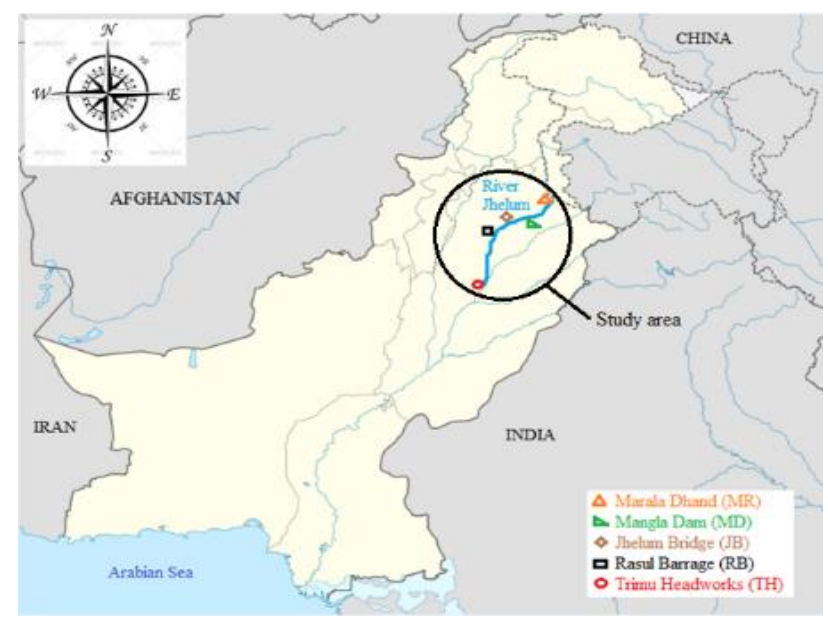

Figure 1. Sampling localities of C. marulius populations. 


\section{Polyacrylamide Gel Electrophoresis}

After amplification of microsatellite loci, $5 \mu$ l of the PCR product was mixed with $1 \mu$ I DNA loading dye and run on polyacrylamide gel for resolution at standard conditions. The bands in gel were visualized by silver staining and scored manually.

\section{Data Analyses}

To describe the genetic constitution of studied fish populations, various indices of genetic diversity and population genetic structure were analyzed by using different software's. Number of alleles $(\mathrm{Na})$, allele frequency, allelic richness $(A r)$, inbreeding $\left(F_{I S}\right)$, observed $(\mathrm{Ho})$ and expected heterozygosity $(\mathrm{He})$ were calculated with FSTAT Ver. 2.9.3 (Goudet, 2002). The sampled populations were tested for deviation from Hardy-Weinberg equilibrium (HWE) across each locus using Markov-chain random walk algorithm employed by ARLEQUIN, Ver. 2.000 (Schnieder, Roessli, \& Excoffier, 2000).

The statistical significance of deviation from HWE was adjusting sequential Bonferroni correction (Rice, $1989)$ to maintain a within-sample type-I error rate of $\alpha=0.05$ for each locus.

Hierarchical partition of genetic diversity was assessed by the analysis of molecular variance (AMOVA) (Excoffier, Smouse, \& Quattro, 1992) using ARLEQUIN, Ver. 2.000. TFPGA software was used to construct UPGMA dendrogram based on genetic distance Nei's (1972). Principle Component Analysis (PCA) was performed by using software PCAGEN ver. 1.2.1 (Goudet, 1999).

\section{Results}

\section{Genetic Diversity}

The number of alleles ranged from 3 to 9 were observed at the examined loci in the present study. The maximum number of alleles was seen 9 in the population of $C$. marulius captured from $\mathrm{TH}$, while the lowest numbers of alleles was observed 3 in the population collected from MR. The allelic richness range was noted from 3.0 to 8.5. Most of the populations showed less heterozygosity at the examined loci (Table 2).

The observed heterozygosity values were recorded ranged from 0.08 to 0.68 while the expected heterozygosity at each locus range were noted from 0.49 to 0.88 . The inbreeding coefficient value ranged was noted from 0.33 to 0.74 . The minimum value of inbreeding coefficient was observed in the population of $\mathrm{TH}$ and high value of inbreeding coefficient was recorded in the population of MR (Table 2). The accessions of gene diversity within $C$. marulius populations was observed ranged from 0.34 to 0.89 . The lowest value of gene diversity (0.34) was observed in the population of MR while the highest value of gene diversity (0.89) was seen in the population of TH (Table 3).

\section{Deviation from $H W E$}

Significant deviation from HWE was detected at various examined loci in the wild populations of $C$. marulius. Maximum deviation was seen in the population of RB at locus $C A-07$ while the minimum was observed in the population of MD at the locus CA-09 (Table 4).

\section{Genetic Structure}

\section{Population Differentiation and Relationship among Populations}

The values of gene flow $(\mathrm{Nm})$ were estimated varied from 0.5644 to 7.6551 at all the examined microsatellite loci in various populations of $C$. marulius. The highest value of gene flow (7.6551) was observed among the populations of $M R$ and $M D$ with the minimum population differentiation ( $\left.F_{\mathrm{ST}}=0.000001\right)$. The lowest value of gene flow (0.5644) was observed between the populations of MR and $\mathrm{TH}$ with maximum

Table 1 Characteristics of Microsatellite loci used for cross-species amplification in C. marulius

\begin{tabular}{|c|c|c|c|c|}
\hline Gene Bank accession no. & Locus & Repeat motif & Primer sequence & $\mathrm{T}_{\mathrm{a}}\left({ }^{\circ} \mathrm{C}\right)$ \\
\hline \multirow[t]{2}{*}{ GU253344 } & CA05 & $(\mathrm{GT})_{18}$ & F: ACTAATCTCTGGTCGTCTCC & 56 \\
\hline & & & R: ATGAATGATAGCCTCTGGTG & \\
\hline \multirow[t]{2}{*}{ GU253347 } & CAO7 & $(G T)_{28}$ & F: ATACGGTAGTTTGACGGTGG & 55 \\
\hline & & & R: GTCTGACCTTCCAAAACTG & \\
\hline \multirow[t]{2}{*}{ GU253348 } & CA08 & $(\mathrm{TG})_{13}$ & F: CTGATGTCCAATCGTGAAGG & 55 \\
\hline & & & R: CTCCCACCAACTGAGAAACT & \\
\hline \multirow[t]{2}{*}{ GU253349 } & CAO9 & $(\mathrm{CA})_{11}$ & F: CTACACCTGGGTTTTTCACAC & 58 \\
\hline & & & R: CTTCACCTTCTACTTCTGGAG & \\
\hline \multirow[t]{2}{*}{ GU253350 } & CA10 & $(C A)_{20}$ & F: ACTGTGTCTTGCTCTTGTCTG & 58 \\
\hline & & & R: CAGGCAAGTAAGCACAATTC & \\
\hline
\end{tabular}


value $\left(F_{\mathrm{ST}}=0.231955\right)$ of population differentiation (Table 5).

Analysis of molecular variance (AMOVA) specified $62.05 \%$ of variation lie among the populations, $4.92 \%$ among individuals within the population, and $33.03 \%$ within the populations (Table 6).

\section{Clustering Analysis}

On the basis of genetic identity computed by Nei's (1972) showed two major clusters or clades which predict that the populations in both clusters have close genetic relationship (Figure 2). The first cluster shows that the populations of $C$. marulius collected from $\mathrm{TH}$, $M D$ and $M R$ are genetically close to each other while in the second cluster populations JB and RB showed similar genetic identity but are distinct from other three populations. The first cluster was further subdivided into two subgroups which comprises the populations of MR and MD. Principle component analysis $(P C A)$ was also performed which showed three major clusters of five populations on the basis of genetic identity (Figure 3).

\section{Discussion}

Genetic diversity is prerequisite at inter and intraspecies level for adaptations over in dynamic environment and conservation of species (Schaal, Leverich, \& Rogstad, 1991). The various aspects of conservation studies for example loss of genetic

Table 2. Individual microsatellite locus statistics for the $C$. marulius populations

\begin{tabular}{|c|c|c|c|c|c|c|c|}
\hline \multirow{2}{*}{ Populations } & \multirow{2}{*}{ Parameters } & \multicolumn{5}{|c|}{ Locus } & \multirow{2}{*}{ Average } \\
\hline & & CA05 & CA07 & CA08 & CAO9 & CA10 & \\
\hline \multirow{5}{*}{ MR } & $\mathrm{Na}$ & 3.000 & 3.000 & 5.000 & 6.000 & 8.000 & 5.0000 \\
\hline & $A r$ & 3.000 & 3.067 & 5.000 & 6.050 & 8.080 & 5.0394 \\
\hline & $\mathrm{Ho}$ & 0.2400 & 0.0800 & 0.2800 & 0.1200 & 0.1600 & 0.176 \\
\hline & $\mathrm{He}$ & 0.6335 & 0.7412 & 0.7649 & 0.8318 & 0.8457 & 0.76342 \\
\hline & FIS & 0.564 & 0.887 & 0.638 & 0.846 & 0.799 & 0.7468 \\
\hline \multirow{5}{*}{ MD } & $\mathrm{Na}$ & 3.000 & 4.000 & 6.000 & 5.000 & 8.000 & 5.2000 \\
\hline & $A r$ & 3.000 & 4.551 & 5.933 & 4.884 & 7.723 & 5.2182 \\
\hline & $\mathrm{Ho}$ & 0.2000 & 0.4800 & 0.6000 & 0.4400 & 0.3600 & 0.4160 \\
\hline & $\mathrm{He}$ & 0.4955 & 0.7388 & 0.7576 & 0.7176 & 0.8498 & 0.7118 \\
\hline & FIS & 0.522 & 0.326 & 0.172 & 0.351 & 0.581 & 0.3904 \\
\hline \multirow{5}{*}{$J B$} & $\mathrm{Na}$ & 3.000 & 4.000 & 6.000 & 9.000 & 8.000 & 6.000 \\
\hline & $A r$ & 3.893 & 4.063 & 5.690 & 8.502 & 7.821 & 5.9938 \\
\hline & Ho & 0.2400 & 0.2000 & 0.2800 & 0.5200 & 0.2400 & 0.2960 \\
\hline & $\mathrm{He}$ & 0.6433 & 0.7992 & 0.7780 & 0.8514 & 0.8465 & 0.7837 \\
\hline & FIS & 0.550 & 0.671 & 0.530 & 0.415 & 0.716 & 0.5764 \\
\hline \multirow{5}{*}{ RB } & $\mathrm{Na}$ & 3.000 & 4.000 & 6.000 & 5.000 & 7.000 & 5.000 \\
\hline & $A r$ & 3.000 & 4.000 & 6.091 & 5.007 & 6.872 & 4.994 \\
\hline & Ho & 0.5000 & 0.4231 & 0.4615 & 0.3077 & 0.4231 & 0.4231 \\
\hline & $\mathrm{He}$ & 0.6506 & 0.7698 & 0.8269 & 0.7665 & 0.8220 & 0.7672 \\
\hline & FIS & 0.440 & -0.032 & 0.390 & 0.399 & 0.330 & 0.3182 \\
\hline \multirow{5}{*}{$\mathrm{TH}$} & $\mathrm{Na}$ & 3.000 & 4.000 & 6.000 & 9.000 & 9.000 & 6.2000 \\
\hline & $A r$ & 3.007 & 4.000 & 6.678 & 8.569 & 8.499 & 6.1506 \\
\hline & Ho & 0.3200 & 0.6800 & 0.4400 & 0.4800 & 0.5200 & 0.488 \\
\hline & $\mathrm{He}$ & 0.7044 & 0.7783 & 0.8582 & 0.8839 & 0.8544 & 0.81584 \\
\hline & FIS & 0.033 & 0.290 & 0.414 & 0.642 & 0.483 & 0.3724 \\
\hline
\end{tabular}

*Na- Observed number of alleles per locus; Ar- Allelic Richness per locus and population; Nei's (1973) Estimation of Ho- Observed Heterozygosity and He- Expected Heterozygosity; FIS- Coefficient of Inbreeding

Table 3. Genetic variability within C. marulius populations revealed by Microsatellite

\begin{tabular}{lcccccc}
\hline & \multicolumn{5}{c}{ Populations } \\
\cline { 2 - 7 } Locus & MR & MD & JB & RB & TH & Average \\
\hline CA05 & 0.349 & 0.654 & 0.549 & 0.656 & 0.747 & 0.591 \\
CA07 & 0.749 & 0.742 & 0.759 & 0.772 & 0.775 & 0.7594 \\
CA08 & 0.752 & 0.755 & 0.780 & 0.840 & 0.853 & 0.796 \\
CA09 & 0.832 & 0.707 & 0.855 & 0.780 & 0.893 & 0.8134 \\
CA10 & 0.853 & 0.860 & 0.849 & 0.829 & 0.852 & 0.8486 \\
\hline
\end{tabular}


Table 4. Deviation from Hardy-Weinberg genotype frequency expectations for five populations at five microsatellite loci

\begin{tabular}{lccccc}
\hline \multirow{2}{*}{ Populations } & \multicolumn{5}{c}{ Locus } \\
\cline { 2 - 5 } & CAO5 & CAO7 & CA08 & CAO9 & CA10 \\
\hline MR & $0.0385^{*}$ & $0.1432^{\text {ns }}$ & $0.2017^{\text {ns }}$ & $0.1131^{\text {ns }}$ & $0.1008^{\text {ns }}$ \\
MD & $0.0029^{*}$ & $0.2017^{\text {ns }}$ & $0.6666^{\text {ns }}$ & $0.0486^{*}$ & $0.0014^{*}$ \\
JB & $0.0068^{\text {ns }}$ & $0.0040^{*}$ & $0.0013^{*}$ & $0.0056^{\text {ns }}$ & $0.0017^{*}$ \\
RB & $0.0257^{*}$ & $0.0001^{* * *}$ & $0.0050^{*}$ & $0.0002^{*}$ & $0.0030^{*}$ \\
TH & $1.0000^{\text {ns }}$ & $0.1550^{*}$ & $0.0044^{*}$ & $0.0115^{\text {ns }}$ & $0.3300^{\text {ns }}$ \\
\hline
\end{tabular}

* Statistically significant values were marked with asterisks.

$\left({ }^{*} \mathrm{P}<0.05,{ }^{* *} \mathrm{P}<0.01,{ }^{* * *} \mathrm{P}<0.001\right.$, ${ }^{\text {ns }}$ - Non significant)

Table 5. Gene flow (Nm) (above diagonal) and Genetic differentiation (FST) (below diagonal) for pair of $C$. marulius populations across all loci

\begin{tabular}{|c|c|c|c|c|c|}
\hline Populations & MR & $\mathrm{MD}$ & $\mathrm{JB}$ & $\mathrm{RB}$ & $\mathrm{TH}$ \\
\hline $\mathrm{MR}$ & - & 7.6551 & 3.2110 & 1.3250 & 0.5644 \\
\hline MD & $0.000001^{* * *}$ & - & 2.4531 & 2.5654 & 0.6323 \\
\hline$J B$ & $0.015156^{*}$ & $0.000237^{* * *}$ & - & 1.4672 & 0.6040 \\
\hline RB & $0.023215^{*}$ & $0.005158^{* *}$ & $0.052409^{n s}$ & - & 6.4644 \\
\hline $\mathrm{TH}$ & $0.231955^{\text {ns }}$ & $0.016428^{*}$ & $0.077795^{\text {ns }}$ & $0.000200^{* * *}$ & - \\
\hline
\end{tabular}

Table 6. Hierarchical AMOVA analysis of five C. marulius populations

\begin{tabular}{lcccc}
\hline Source of variation & d.f. & SOS & Variance & Percentage of variation \\
\hline Among populations & 4 & 77.067 & 0.9294 & 62.05 \\
Among individual within populations & 114 & 18.543 & 0.0832 & 4.92 \\
Within populations & 119 & 113.011 & 0.5201 & 33.03 \\
\hline Total & 237 & 208.621 & 1.5327 & \\
\hline
\end{tabular}

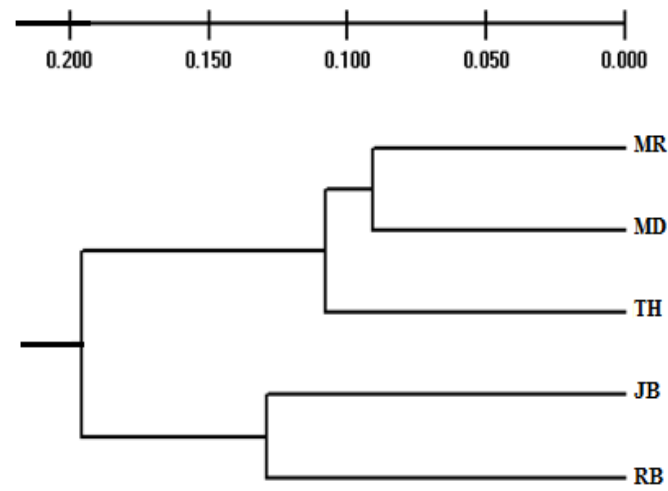

Figure 2. The UPGMA dendrogram based on pairwise value of genetic identity computed by Nei's (1972) between five $C$. marulius populations.

variability and restoration of near threatened species can only be implemented by detailed studies of their population genetic structure. Due to loss of genetic variability, to high level of inbreeding within and among populations that can be driven by random genetic drift, populations are declining (Ellstrand \& Elam, 1993).

The current study was conducted for the evaluation of genetic polymorphism in $C$. marulius populations using microsatellite DNA markers. The moderate to high level of genetic variability was detected among these populations. Maximum allelic richness was observed in population $\mathrm{TH}$ which shows high genetic variability as compared to other populations may be due to comparatively large effective population size. These findings are according to the results conducted by (Jamaluddin, Pau, \& Siti-Azizah, 


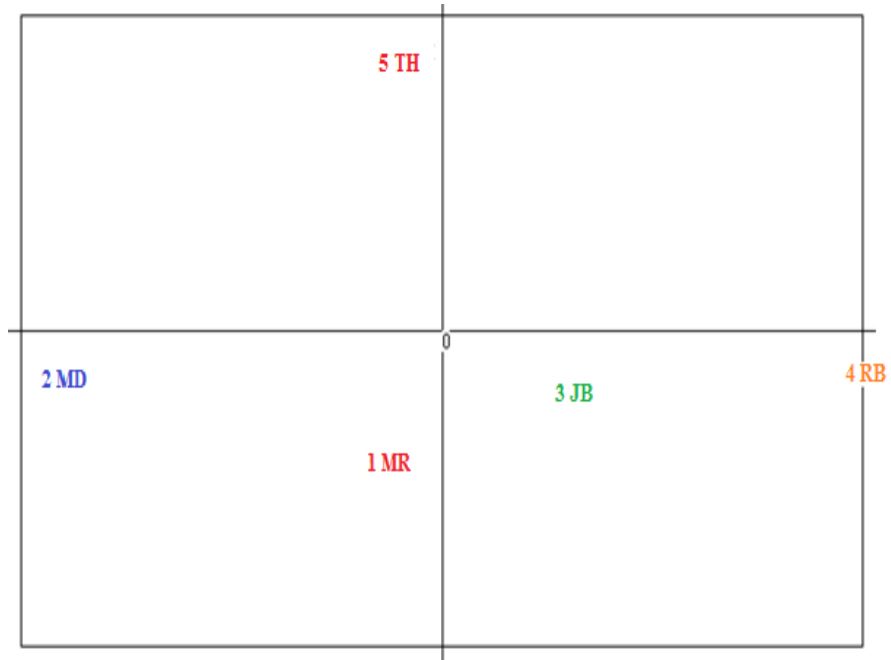

Figure 3 Principle Component Analysis of five populations of $C$. marulius

2011) where they found high genetic variability among upstream populations of $C$. striatus by the analysis of Cytochrome c oxidase subunit I (Cox I).

A null allele is any allele which amplified on microsatellite but does not visible after staining or electrophoretic separation (O'Connell \& Wright, 1997). The presence of null alleles is an important element of loss of heterozygosity as compared to expected heterozygosity as observed in the present study in population MR which shows loss of observed heterozygosity due to presence of maximum number of null alleles. The reason of presence of null alleles by the analysis of microsatellite marker is thought to have the incident of mutation for example insertion and deletion (Callen, Thompson, Shen, Phillips, Richards, Mulley, \& Sutherland, 1993). Similar results were conducted by Alam, (2012) in their research and find out the same possible reason of loss of heterozygosity among Cyprinus carpio populations due to presence of null alleles. Because of less effective population size colonization of fish species occurs in wild population which cause the high rate of inbreeding and ultimately lead to loss of genetic variability (Ramstad, Woody, Sage, \& Allendorf, 2004). Our study also indicated the genetic loss in population MR as a result of high rate of inbreeding. Thai, Burridge, and Austin, (2007) also reported the loss of genetic variability due to inbreeding in wild population of common carp (C. carpio); Ahmed and Abbas (2018) in hatchery populations of Catla catla as compared to natural stock of $C$. catla by using microsatellite marker.

Being an important commercial fish several plausible factors may include which cause the loss of genetic variability. The factors such as habitat loss, over exploitation (Hauser, Adcock, Smith, Bernal, \& Carvalho, 2002) and environmental inconstancy including human activities (Wang, Zhou, Ye, Wei, \& Wu, 2006) which results into bottleneck disorder (Newman \& Pilson, 1997) that may lead to inbreeding. In the present study genetic variability within accessions of $C$. marulius populations the highest gene diversity was seen in population TH while the lowest was observed in population MR. The low genetic variation among this population may be due to the reason of historical bottleneck as assessed by Jamaluddin et al. (2011) in their study on genetic variability in Snakehead murrel, $C$. striatus.

Significant deviation from Hardy-Weinberg equilibrium was observed almost among all the populations except on some loci of the population MR and MD. This shows that these populations are on equilibrium and complied the random mating hypothesis. Alam and Islam (2005) were also observed the significant deviation from HWE in different loci of the populations of Catla catla.

According to Wright (1978) genetic differentiation (FST) values ranging in between 0 to 0.050 shows very less genetic differentiation, 0.050 to 0.150 designate moderate level of genetic differentiations, 0.150 to 0.250 indicate sufficient differentiation and values above 0.250 show as very high level of genetic variability. In the present study the pairwise population genetic differentiation (FST) was fall between moderate to high level of genetic differentiation. The lowest genetic differentiation was present in between populations MR and MD while maximum genetic differentiation was observed in between populations $\mathrm{MR}$ and $\mathrm{TH}$ possibly due to the reason of restricted dispersion of populations because of geographical distance. Similar results were conducted by Habib, Lakra, Mohindra, Khare, Barman, Singh, Lal, Punia, and Khan, (2011) in their studies where they found high level of genetic differentiation among $C$. marulius populations.

Lack of genetic differentiation among adjacent populations is not so unexpected. But when distant populations show less genetic differentiation then demographic and historical ecology explanations are the main factors for the justification of such less genetic differentiation and may include the ancient connectivity 
among populations (Steven, 2004). As observed in the present study between populations $\mathrm{TH}$ and JB which has less genetic differentiation but large geographical distance. The extraordinary capability of $C$. marulius fish species to breath in air and so stay alive during transportation and the economically importance of this fish are the reasons to introduce this specie into nonindigenous regions. In this case the populations $\mathrm{TH}$ and $M D$ strongly in the favor of human mediated translocations. Because they have less genetic differentiation while have large geographical distance. There is one report documenting that in 1950's the transportation of live $C$. striatus populations occurs from Borneo to Singapore as well as unintentional translocations by human activities also reported in past (Schuster, 1952).

C. marulius generally considered as local migrant who prefers to find food in nearby its habitat as much as possible and avoid going far away for feeding purpose. And also travels very short distance for their breeding grounds in order to avoid predator or any other factor which cause stress in their habitats (Chondar, 1999). The gene flow $(\mathrm{Nm})$ values obtained showed the migration of the number of individuals from one specific population to other population with the estimated gene flow according to island model of Wright (1978). On the basis of present study maximum gene flow was observed among populations $\mathrm{MR}$ and $\mathrm{MD}$ with minimum genetic differentiation. The reason could be partial isolation among populations, climatic factors (Rahim, Rozila, \& Mat Jais, 2009) and especially intrusion of human intervention which transfer populations from one locality to the other (Nazia, Suzana, Azhar, Nguyen, \& Siti Azizah, 2010). Minimum gene flow was present in between populations MR and TH with maximum genetic differentiation. A sufficiently high gene flow was also observed in between populations RB and TH maybe due to the reason of climatic changes. Another important factor is the occurrence of natural disaster like flood regularly almost in every year during monsoon rains and also human mediated translocations as reported by Rahim, Ismail, Alias, Muhammad, and Jais, (2012) in their study and gives the same possible reasons of gene flow among populations.

Occurrence of genetic variability within populations, among populations as well as within individual among populations is necessary for species survival and positive response towards environmental fluctuations (Ryman \& Laikre, 1995). To determine the genetic variability within population and among population AMOVA (Analysis of molecular variance) of C. marulius was performed with total of five populations. AMOVA analysis showed maximum variations among populations and minimum among individual within the population itself. More variability among populations could be due to the recent expansion of the population which merged in very short time duration or maybe due to the interconnection of the areas. Interestingly similar findings were observed by Jamaluddin et al. (2011) in their study. They found higher variations among populations and lower variation within populations $89.8 \%$ and $10.11 \%$, respectively.

Clustering order reflects relationship among populations. UPGMA dendrogram constructed on the basis of Nei' (1972) genetic distance with 1000 permutation showed two major clusters. The clustering analysis on the basis of genetic identity is apposite to geographical distance. Li, Kang, Yin, and Sun (2007) reported that the populations close to each other showed maximum genetic identity because of high gene flow and vice versa. The first cluster was further subdivided into two sub-clusters $M R, M D$ and $T H$ in which populations MR and MD showed close genetic relationship may be due to the smaller geographical distance and sharing of same parental populations. Another reason of both the populations MR and MD on the same clade could be due to the recent expansion among $C$. marulius populations as reported by Rahim et al. (2012).

In the present study principle component analysis (PCA) plot was constructed to represent the scattering of populations on the basis of correlation among populations. Isolation of population for a longer period conspicuously because of geographical barrier may cause development of variable characteristics in populations. In the isolated population independently, evolutionary processes occur (Steven, 2004). These results formed total of three clusters and scattered in three coordinates. The first cluster in which population $\mathrm{TH}$ was present shows significant distinction from all other populations due to significant greater of population differentiation (FST). The reason could be geographical distance from all other populations due to the presence of certain kind of physical barrier. The two populations are present in remaining two clusters which showed similar genetic identity in which populations MR and MD are similar enough present on left coordinates and populations JB and RB shows close relationship present on the right side of the coordinates. Because population TH was on same cluster with populations MR and MD on UPGMA dendrogram so they are present on same left coordinate.

\section{Conclusion}

According to the present study human mediated translocations between these populations are not recommended to avoid the genetic deterioration (Jørstad \& Farestveit, 1999), intrusion of disease (Mahidol, Na-Nakorn, Sukmanomon, Taniguchi, \& Nguyen, 2007) or the adverse competition between populations (Minckley, 1995). Habitat deterioration among these populations observed due to industrial activities, agriculture run off and construction of dams on river cause the limited connectivity between 
populations which reduce the effective population size or increase inbreeding depression. These anthropogenic activities must be carefully regulated and according to these management strategies should be applied to prevent further habitat fragmentation. Based on high genetic variations and positive contribution toward increase in genetic variability, populations $\mathrm{TH}$ and $\mathrm{RB}$ are considered the most appropriate candidate for the production of potential broodstock for selective breeding programmes. But hatchery operations and selection of potential broodstock need to be systematically checked and regulated to avoid the further genetic contamination to the wild populations (Mahidol et al., 2007). As the population TH harbor a high proportion of genetic variations among all the populations so this area must be in the priority for the conservation and management strategies.

These findings on the study of population genetic structure of $C$. marulius populations would be fruitful for management strategies in fishery management sector at government or semi-government level. These findings recommend that the large population size and sample location on broader range of geographical scale are needed to support the hypothesis regarding genetic distance and genetic differentiation and for the variation among and within populations of $C$. marulius.

\section{Acknowledgement}

The author expresses their sincere thanks to senior PhD scholars of Aquaculture Biotechnology Lab, Department of Zoology, Wildlife and Fisheries, University of Agriculture, Faisalabad, Pakistan for their scholarly guidance and constant encouragement during this research work.

\section{References}

Ahmed, T. \& K. Abbas. (2018). Patterns of genetic variability in natural and hatchery populations of Catla catla based on microsatellite DNA markers. Pakistan Journal of Agricultural Sciences, 55(4), 929-939.

Alam, M.N., \& Alam, M.S. (2012). Genetic variation in three captive populations of two strains of common carp (Cyprinus carpio L.) in Bangladesh revealed by microsatellite DNA markers. Global Journal of BioScience and Biotechnology, 1(2), 223-228.

Alam, M.S., and Islam, M.S. (2005). Population genetic structure of Catla catla (Hamilton) revealed by microsatellite DNA markers. Aquaculture, 246(1-4), 151160. https://doi.org/10.1016/j.aquaculture.2005.02.012

Berra, T.M. (2007). Freshwater Fish Distribution: Chicago, University of Chicago Press., 615 pp.

Callen, D.F., Thompson, A.D., Shen, Y., Phillips, H.A., Richards, R.I., Mulley, J.C., \& Sutherland, G.R. (1993). Incidence and origin of "null" alleles in the (AC)n microsatellite markers. The American Journal of Human Genetics, 52(5),

922-927.
Molur, S., \& Walker, S. (1998). Report of the Workshop Conservation Assessment and Management Plan (CAMP) for Freshwater Fishes of India. (Report No. 18). Zoo Outreach Organization and National Bureau of Fish Genetic Resources, Lucknow, India, 156 pp.

Chistiakov, D.A., Hellemans, B., \& Volckaert, F.A.M. (2006). Microsatellites and their genomic distribution, evolution, function and applications: A review with special reference to fish genetics. Aquaculture, 255(1-4), 1-29. https://doi.org/10.1016/j.aquaculture.2005.11.031

Chondar, S.L. (1999). Biology of Fin Fishes and Shellfishes: Howrah, India, SCSC Publishers., 514 pp.

Ellstrand, N.C., \& Elam, D.R. (1993). Population genetic consequences of small population size: implications for plant conservation. Ecology and Systematics, 24, 217242. https://doi.org/10.1146/annurev.es.24.110193.001245

Estoup, A., \& Angers, B. (1998). Microsatellites and minisatellites for molecular ecology: theoretical and empirical considerations. In G.R. Carvalho (Eds.), Advances in Molecular Ecology (pp. 55-86). France, Italy, IOS Press.

Excoffier, L., Smouse, P.E., \& Quattro, J.M. (1992). Analysis of molecular variance inferred from metric distances among DNA haplotypes: application to human mitochondrial DNA restriction data. Genetics, 131(2), 479-491.

Goudet, J. (1999). PCAGEN, ver. 1.2.1. Retrieved from http://www2.unil.ch/popgen/softwares/pca gen.htm

Goudet, J. (2002). FSTAT version 2. 9. 3. A program to estimate and test gene diversities and fixation indices. Institute of Ecology and Evolution, University of Lausanne, Switzerland. Retrieved from http://www2. unil. ch/popgen/softwares/fstat. htm

Habib, M., Lakra, W.S., Mohindra, V., Khare, P., Barman, A.S., Singh, A., Lal, K.K., Punia, P., \& Khan, A.A. (2011). Evaluation of cytochrome $b$ mtDNA sequences in genetic diversity studies of Channa marulius (Channidae: Perciformes). Molecular Biology Reports, 38(2), 841846. https://doi: 10.1007/s11033-010-0175-2.

Haniffa, M.A., Nagarajan, M., Gopalakrishnan, A., \& Musammilu, K.K. (2007). Allozyme Variation in a Threatened Freshwater Fish, Spotted Murrel (Channa punctatus) in a South Indian River System. Biochemical Genetics, 45(3-4), 363-374. https://doi: 10.1007/s10528007-9080-3

Hauser, L., Adcock, G.J., Smith, P.J., Bernal, J.H.R., \& Carvalho, G.R. (2002). Loss of microsatellite diversity and low effective population size in an overexploited population of New Zealand snapper (Pagrus auratus). Proceedings of the National Academy of Sciences of the United States of America, 99(18), 11742-11747. https://doi.org/10.1073/pnas.172242899

Jamaluddin, J.A.F., Pau, T.M., \& Siti-Azizah, M.N. (2011). Genetic structure of the snakehead murrel, Channa striata (channidae) based on the cytochrome c oxidase subunit I gene: Influence of historical and geomorphological factors. Genetics and Molecular Biology, 34(1), 152-160. https://doi: 10.1590/S141547572011000100026

Jarne, P., \& Lagoda, P.J.L. (1996). Microsatellites, from molecules to populations and back. Trends in Ecology 
and Evolution, 11(10), 424-429. https://doi:10.1016/0169-5347(96)10049-5

Jørstad, K. E., \& Farestveit, E. (1999). Population genetic structure of lobster Homarus gammarus in Norway, and implications for enhancement and sea-ranching operation. Aquaculture, 173(1-4), 447-457. https://doi.org/10.1016/S0044-8486(98)00475-X

Li, D., Kang, D., Yin, Q., \& Sun, X. (2007). Microsatellite DNA marker analysis of genetic diversity in wild common carp (Cyprinus carpio L.) populations. Journal of Genetics and Genomics, 34(11), 984-993. https://doi:10.1016/S16738527(07)60111-8

Mahidol, C., Na-Nakorn, U., Sukmanomon, S., Taniguchi, N., \& Nguyen, T.T.T. (2007). Mitochondrial DNA diversity of the Asian moon scallop, Amusium pleuronectes (Pectinidae), in Thailand. Marine Biotechnology, 9(3), 352-359. https://doi:10.1007/s10126-006-6137-y

Minckley, W.L. (1995). Translocation as a tool for conserving imperiled fishes: Experiences in Western United States. Biological Conservation, 72(2) 297-309. https://doi.org/10.1016/0006-3207(94)00091-4

Mirza, Z.S., Mirza, M.R., \& Javed, M.N. (2006). Fishes of River Jhelum from Mangla to Jalalpur near Head Rasool. Biologia, 52, 215-227.

Musikasinthorn, P. \& Taki, Y. (2001). Channa siamensis (Günther, 1861), a junior synonym of Channa lucius (Cuvier in Cuvier and Valenciennes, 1831). Ichthyological Research, 48(3), 319-324. https://doi.org/10.1007/s10228-001-8153-2

Nazia, A.K., Suzana, M., Azhar, H., Nguyen, T.T., \& Siti Azizah, M.N. (2010). No genetic differentiation between geographically isolated populations of Clarias microcephalus Günther in Malaysia revealed by sequences of mtDNA cytochrome $b$ and D-loop gene regions. Journal of Applied Ichthyology, 26(4), 568570. https://doi.org/10.1111/j.14390426.2010.01469.x

Nei, M. (1972). Genetic distance between populations. The American Naturalist, 106(949), 283-292. https://www.jstor.org/stable/2459777

Nei, M. (1973). Analysis of gene diversity in subdivided populations. Proceedings of the National Academy of Sciences of the United States of America, 70(12), 33213323. https://doi: 10.1073/pnas.70.12.3321

Nei, M. (1978). Estimation of average heterozygosity and genetic distance from a small number of individuals. Genetics, 89(3), 583-590.

Newman, D., \& Pilson, D. (1997). Increased probability of extinction due to decreased genetic effective population size: experimental populations of Clarkia pulchella. Evolution, 51(2), 354-362. https://doi: 10.1111/j.15585646.1997.tb02422.x

O'Connell, M., \& Wright, J.M. (1997). Microsatellite DNA in fishes. Review in Fish Biology and Fisheries, 7(3), 331363.

Peakall, R., Gilmore, S., Keys, W., Morgante, M., \& Rafalski, A. (1998). Cross-species amplification of Soybean (Glycinemax) simple sequence repeats (SSRs) with in the genus and other legume genera: Implications for the transferability of SSRs in Plants. Molecular Biology and Evolution, 15(10), 1275-1287. https:// doi: 10.1093/oxfordjournals.molbev.a025856

Rafique, M., Ul, N., \& Khan, H. (2012). Distribution and status of significant freshwater fishes of Pakistan. Records Zoological Survey of Pakistan, 21, 90-95.
Rahim, M.H.A., Rozila, A., \& Mat Jais, A.M. (2009). The physical-chemical and morphological study of Haruan Channa striatus in Peninsular Malaysia. Research Journal of Biological Sciences, 4(9), 994-1009. https://doi=rjbsci.2009.994.1009

Rahim, M.H.A., Ismail, P., Alias, R., Muhammad, N., \& Jais, A.M. (2012). PCR-RFLP analysis of mitochondrial DNA cytochrome $b$ gene among Haruan (Channa striatus) in Malaysia. Gene, 494(1), 1-10. https://doi: 10.1016/j.gene.2011.12.015

Ramstad, K.M., Woody, C.A., Sage, G.K., \& Allendorf, F.W. (2004). Founding events influence genetic population structure of sockeye salmon (Oncorhynchus nerka) in Lake Clark, Alaska. Molecular Ecology, 13(2), 277-290.

Rice, W.R. (1989). Analyzing table of statistical tests. Evolution, 43(1), 223-225.

Ryman, N., U., \& Laikre, L. (1995). Protection of intra-specific biodiversity of exploited fishes. Reviews in Fish Biology and Fisheries, 5(4), 417-446. https://doi: 10.1007/BF01103814

Schaal, B.A., Leverich, W.J., \& Rogstad, S.H. (1991). Comparison of methods for assessing genetic variation in plant conservation biology. In D.A. Falk \& K.E. Holsinger (Eds.), Genetics and conservation of rare plants (pp. 123-134). New York, Oxford University Press.

Schneider, S., Roessli, D., \& Excoffier, L. (2000). ARLEQUIN version. 2.0: A software for population genetics data analysis. Genetics and Biometry Laboratory, University of Geneva, Switzerland.

Schuster, W.H. (1952). A provisional survey of the introduction and transplantation of fish throughout the Indo-Pacific region. Third IPFC Fisheries Symposium (pp. 187-196). Bogor, Indonesia.

Scribner, K.T., \& Pearce, J.M. (2000). Microsatellites: Evolutionary and Methodological Background and Empirical Applications at Individual, Population, and Phylogenetic Levels. In A. Baker (Eds.), Molecular Methods in Ecology (pp. 235-271). Blackwell Science Ltd., London, England.

Steven, T.K. (2004). Counting alleles with rarefaction: Private alleles and hierarchical sampling designs. Conservation Genetics, 5(4), 539-543.

Thai, B.T., Burridge, C.P., \& Austin, C.M. (2007). Genetic diversity of common carp (Cyprinus carpio L.) in Vietnam using four microsatellite loci. Aquaculture, 269(1-4), 174186. https://doi.org/10.1016/j.aquaculture.2007.05.017

Utter, F.M. (1991). Biochemical genetics and fishery management: an historical perspective. Journal of Fish Biology, 39, 1-20. https://doi.org/10.1111/j.10958649.1991.tb05063.x

Wang, Z.W., Zhou, J.F., Ye, Y.Z., Wei, Q.W., \& Wu, Q.J. (2006). Genetic structure and low genetic diversity suggesting the necessity for conservation of the Chinese Longsnout Catfish, Leiocassis longirostris (Pisces: Bagriidae). Environmental Biology of Fishes, 75(4), 455-463.

Wright, S. (1978). Evolution and the Genetics of Populations. Vol. 4, Variability within and among Natural Populations, University of Chicago Press., Chicago, 590 pp.

Yue, G.H., \& Orban, L. (2005). A simple and affordable method for high-throughput DNA extraction from animal tissues for polymerase chain reaction. Electrophoresis, 26(16), 3081-3083. https://doi: 10.1002/elps.200410411 